IZA DP No. 6843

Does Emigration Benefit the Stayers?

Evidence from EU Enlargement

Benjamin Elsner

September 2012 


\title{
Does Emigration Benefit the Stayers? Evidence from EU Enlargement
}

\author{
Benjamin Elsner
}

IZA and IIIS

\section{Discussion Paper No. 6843 \\ September 2012}

\author{
IZA \\ P.O. Box 7240 \\ 53072 Bonn \\ Germany \\ Phone: +49-228-3894-0 \\ Fax: +49-228-3894-180 \\ E-mail: iza@iza.org
}

Any opinions expressed here are those of the author(s) and not those of IZA. Research published in this series may include views on policy, but the institute itself takes no institutional policy positions.

The Institute for the Study of Labor (IZA) in Bonn is a local and virtual international research center and a place of communication between science, politics and business. IZA is an independent nonprofit organization supported by Deutsche Post Foundation. The center is associated with the University of Bonn and offers a stimulating research environment through its international network, workshops and conferences, data service, project support, research visits and doctoral program. IZA engages in (i) original and internationally competitive research in all fields of labor economics, (ii) development of policy concepts, and (iii) dissemination of research results and concepts to the interested public.

IZA Discussion Papers often represent preliminary work and are circulated to encourage discussion. Citation of such a paper should account for its provisional character. A revised version may be available directly from the author. 
IZA Discussion Paper No. 6843

September 2012

\section{ABSTRACT}

\section{Does Emigration Benefit the Stayers? Evidence from EU Enlargement}

Around 9\% of the Lithuanian workforce emigrated to Western Europe after the enlargement of the European Union in 2004. I exploit this emigration wave to study the effect of emigration on wages in the sending country. Using household data from Lithuania and work permit and census data from the UK and Ireland, I demonstrate that emigration had a significant positive effect on the wages of stayers. A one percentage-point increase in the emigration rate predicts a $0.67 \%$ increase in real wages. This effect, however, is only statistically significant for men.

JEL Classification: F22, J61, R23

Keywords: emigration, labor mobility, EU enlargement

Corresponding author:

Benjamin Elsner

IZA

P.O. Box 7240

53072 Bonn

Germany

E-mail: elsner@iza.org

\footnotetext{
* I am grateful to Gaia Narciso for all her support and encouragement. I would also like to thank the editor, three anonymous referees, Catia Batista, Karol Borowiecki, John FitzGerald, Ulrich Gunter, Julia Anna Matz, Corina Miller, Mrdjan Mladjan, Alfredo Paloyo, Todd Sorensen, Pedro Vicente and Michael Wycherley, as well as the seminar participants at the 6th ISNE conference in Limerick/IE, the 3rd RGS doctoral conference in Bochum/GER, the 24th Irish Economic Association annual conference in Belfast/UK and the TCD Development Working Group for helpful comments. The Lithuanian and Irish Statistical Offices were very helpful in providing the data. I gratefully acknowledge funding from the Irish Research Council for the Humanities \& Social Sciences (IRCHSS) and the Department of Economics at Trinity College Dublin. The paper has been conditionally accepted at the Journal of Population Economics. All errors are mine.
} 


\section{INTRODUCTION}

Migration affects both sending and receiving countries. While a vast literature documents the impact of migration on wages and employment in the receiving countries, there is only sparse evidence on its impact on the sending countries. ${ }^{1}$

In this paper I exploit the emigration wave from Lithuania after the enlargement of the European Union to study the effect of emigration on wages in the sending countries. With EU enlargement in 2004, Lithuanian workers were allowed to migrate without restrictions to the United Kingdom (UK), Ireland and Sweden. Between 2004 and 2007, around 9\% of the workforce took this opportunity and emigrated to the UK and Ireland. The large emigration wave - caused by a change in the institutional framework - makes Lithuania an ideal case study of a sending country.

To identify the effect of emigration on wages, I use the skill-group approach proposed by Borjas (2003). This approach clusters the workforce in a number of skill groups defined by gender, education, and work experience - and compares emigration rates and real wages within each skill group before and after EU enlargement.

Using microdata from Lithuania, and work permit and census data from the UK and Ireland, I show that emigration has a significant positive effect on the wages of stayers. Groups with larger emigration rates had higher wage increases. A $10 \%$ increase in the emigration rate predicts an average increase in real wages of $6.6 \%$. This positive effect, however, is only statistically significant for men but not for women. Given that emigration was triggered by an exogenous change in migration laws, the results can be interpreted as causal.

The positive effect of migration on wages is consistent with a simple supply-anddemand framework. Migration decreases labor supply, which - given a downward-sloping labor demand curve - leads to an increase in wages. The absence of a statistically signifi-

$1 \quad$ See Kerr and Kerr (2011) and Clemens (2011) for reviews of the literature on the economic effects of migration on receiving and sending countries. 
cant effect for women is surprising, given that women accounted for $40 \%$ of all emigrants. Potential explanations are a positive self-selection of female emigrants, or endogenous responses in labor supply, i.e. women who had not been working previously filled the job of women who emigrated.

The institutional arrangements in the European Union allow me to overcome data constraints that are inherent in the study of sending countries. Sending countries typically do not keep records of emigrants, which makes it difficult to quantify the number of emigrants. With EU enlargement, workers from the new member states were only allowed to migrate to the UK, Ireland, and Sweden. Therefore, it is possible to calculate the number of Lithuanian emigrants from the census and work permit data of these countries.

To be certain, identification faces several challenges. One challenge is omitted variable bias. Wages are determined by numerous factors other than migration, for example FDI inflows, trade, or unemployment. If these factors are omitted from the model, the results may be biased. To tackle this problem, I add a rich set of dummy variables and interaction terms to the regression, which account for changes in the returns to education and experience, and differences in the age-earnings-profile across education groups. In addition, I control for FDI, exports, and unemployment at the regional level. The results are not sensitive to the inclusion of these variables, however.

An additional challenge is self-selection. Average wages may increase, simply because workers from the lower end of the wage distribution have left the country. Given the data on emigrants from the UK and Ireland, it is not possible to assess directly whether emigrants within a skill group were negatively selected. An inspection of the wage distribution in Lithuania before and after EU enlargement, however, does not indicate a negative selection. Moreover, as the receiving countries have on average higher skill requirements, selection should be positive, and the results would be downward-biased.

This paper adds to the literature on the wage effect of emigration, as it shows that 
emigration increases wages in the short run. Previous literature has looked at longstanding migration movements. Using the same approach as this study, Mishra (2007) and Aydemir and Borjas (2007) show that emigration from Mexico to the US has led to a long-run increase in wages in Mexico. Bouton et al. (2011) find similar results for Moldova. This paper, by contrast, exploits a sudden emigration shock to show that emigration increases wages even in the short run. ${ }^{2}$

The EU enlargement was one of the rare occasions in which high-income countries opened their borders for workers in middle-income countries. The results of this study are therefore of interest for middle-income countries that may face a similar situation in the future. If the US, for example, opened its borders for workers from South America, it would be helpful for policymakers in the sending countries to know what fraction of the population they can expect to emigrate, and what consequences this emigration wave has on the labor market.

\section{EU ENLARGEMENT AND MigRATION}

The EU enlargement in May 2004 was a milestone in the process of European integration. 15 years after the fall of the Iron Curtain, 8 former socialist countries from Central and Eastern Europe became members of the European Union. At the time of EU enlargement, the new member states were still in the process of economic transition. Compared to Western Europe, economic output in the new member states was considerably lower, which also translated into substantial wage differentials. In 2004, wage differentials were highest in Latvia and Lithuania, where workers earned on average $30 \%$ of the PPPadjusted wage in the UK. ${ }^{3}$

As wage differentials are a major driving force of international migration, the migra-

2 In a recent paper, Gagnon (2011) uses the emigration wave from Honduras after Hurricane Mitch, and finds wage effects that are similar to those in this paper.

3 Own calculations from Eurostat. 
tion potential in the new member states before EU enlargement was substantial. Studies that estimated the migration potential from the new member states before the enlargement predicted that between 3\% (Bauer and Zimmermann, 1999; Boeri and Brücker, 2001) and 5\% (Sinn, 2004) of the population of the new member states would migrate within 15 years.

With freedom of movement being a core principle of the European Union, the enlargement would have allowed workers from the new member states to work in any other EU country. Policymakers in the old member states, however, feared that a large immigration wave from Eastern Europe could depress wages, increase unemployment (Zaiceva and Zimmermann, 2008), and impose a burden on the welfare state, and decided to give the old member states the option to restrict access to their labor markets until 2011. Only the UK, Ireland, and Sweden opened their labor markets in 2004.

Given the restrictions in other potential destination countries - above all Germany and France - and the good economic conditions in the UK and Ireland, it was no surprise that these two countries were the destination for the majority of workers from Eastern Europe. Between 2004 and 2007 the UK issued around 770,000 and Ireland around 400,000 work permits to workers from the new member states, while only 19,000 workers went to Sweden (Wadensjö, 2007). Elsner (2011) shows that the magnitude of the emigration wave was particularly large in Lithuania. 9\% of all Lithuanian workers received a work permit in the UK and Ireland - in Latvia and Slovakia the share was 6\%, in Poland 5\%. ${ }^{4}$ Most of the emigrants were young, and had a medium to high education level (Zaiceva and Zimmermann, 2008).

A number of studies have evaluated the economic consequences of this migration wave. ${ }^{5}$ Most studies on the receiving countries did not find the effects of the immigration

\footnotetext{
Hungary and the Czech Republic, on the contrary, had outflows of less than $1 \%$.

See Constant (2011) for a review of the most recent literature and Kahanec and Zimmermann (2009) for a collection of country studies on EU enlargement. Barrell et al. (2010) illustrate the macroeconomic consequences of migration on the sending and receiving countries.
} 
wave on wages and employment to be large (Barrett, 2009; Blanchflower and Shadforth, 2009). On the side of the sending countries, the evidence is purely descriptive. Kaczmarczyk et al. (2009) and Hazans and Philips (2009) illustrate that wages in Poland and the Baltic States increased while unemployment decreased after EU enlargement. This paper extends the existing literature, as it presents a first econometric evaluation of the effect of the post-enlargement migration wave on the source countries.

\section{Data And Descriptive Statistics}

To analyze the effect of emigration on wages, one would ideally like to use a micro-dataset that contains information on both emigrants and stayers. Such a dataset, however, is usually not available for the sending countries. In most countries, emigrants are not obliged to de-register, which makes it difficult for the sending countries to keep reliable records on their emigrants. Following Mishra (2007), I use data from the two main destination countries - Ireland and the UK - to calculate the number of Lithuanian emigrants for different groups of workers and match them with stayers from the same groups. The remainder of this section describes the datasets used in this study and explains the calculation of the number of emigrants. ${ }^{6}$

\subsection{Lithuanian Household Budget Survey}

The core dataset of this study is the Lithuanian Household Budget Survey (HBS), which is available for the years 2002, 2003, 2005 and 2006. The HBS is an annual survey of 7,0008,000 households; it is representative at the individual level and contains information on income and expenditure, as well as individual characteristics such as sex, age, education and place of residence. The HBS does not contain information on occupations, industries, or sectors.

$\overline{6} \quad$ The entire section on data is similar to Elsner (2011), which uses the same data sources. 
The sample contains employees aged 18-64 working in the private sector. I exclude public sector workers because wages in the public sector are typically determined by seniority pay and not by supply and demand. In addition, I drop workers with zero or negative disposable income, pensioners, self-employed workers and workers whose main income comes from their own farm.

The variable income from employment, deflated by the HCPI, gives information on real monthly gross wages. As we can see in Table 1a), real wages increased by around $40 \%$ between 2002 to 2006 . Along with the wage level, the standard deviation of wages increased.

A potential concern with household budget surveys is over- or under-reporting of income, which can bias the results. To assess the degree of misreporting bias, I compare the self-reported real wages from the HBS in Table 1a) with the wages from the live register from the Lithuanian Statistical Office in Table 1b). It is reassuring that both sources report similar average real wages, so that misreporting should not bias the results.

\section{[Insert Table 1 here]}

\subsection{IRISH CENSUS}

To obtain the stocks of Lithuanian migrants in Ireland and to determine the migrants' skill distribution I use data from the Irish census in 2002 and 2006.

The Irish census is carried out every 4-5 years and covers the entire population that is present in Ireland in the census night. For the 2002 and 2006 censuses, the Central Statistics Office (CSO) of Ireland provided a tabulation of the number of Lithuanians by their educational attainment, gender and age.

Table 2 reports the characteristics of Lithuanian migrants in Ireland in 2002 and 2006. Most migrants had an upper secondary education and were in their 20s. The number of 
men in 2006 was $30 \%$ higher than the number of women. The difference in the number of Lithuanians in Ireland between 2002 and 2006 shows that the majority must have migrated to Ireland around or after the time of EU enlargement. Notably, the education distribution did not change significantly over time, even though the stock of migrants in 2006 was 10 times higher than in 2002.

Comparing the migrants in Table 2b) to the stayers in Table 1a), we can see that the migrants were on average younger and less educated than stayers. The share of workers with a lower secondary education is larger among migrants, while there are relatively less migrants with an upper secondary or a third-level education. Migrants were on average 12 years younger than stayers.

\section{[Table 2 about here]}

\subsection{IRISH AND UK WORK PERMIT DATA}

To obtain the total number of Lithuanian emigrants, I use work permit data from the UK and Ireland. While the census data reflects a lower bound to the number of migrants, the work permit data is an upper bound of the migration flows from Lithuania to the UK and Ireland. The work permit data captures every person who comes to the UK and Ireland and wants to take up employment, be it for a permanent position or for a temporary job. The number of workers who left the Lithuanian workforce permanently should therefore be lower than the number of work permits.

Figure 1 shows the number of work permits granted to Lithuanians between 2002 and 2007. In total, the number of Lithuanian migrants to the UK and Ireland amounted to 150,000 . As we can see, the migration wave set in with EU enlargement in 2004 and reached its peak in 2005 .

As a measure of the number of work permits I use national insurance numbers (NINo) 
for the UK and personal public service numbers (PPS) for Ireland. ${ }^{7}$ The work permit statistics reflect actual migration, because workers only receive a work permit if they are physically present in the destination country. To obtain a work permit, a worker has to report in person to the Social Welfare Office in Ireland or the Department for Work and Pensions in the UK and produce a proof of address. If a worker moves back-and-forth between Lithuania and either the UK or Ireland, she keeps her work permit, so that repeated migration does not cause double counts. ${ }^{8}$

\section{[Figure 1 about here]}

\subsection{Calculation of Emigrant Numbers}

From the census and work permit data I now construct measures for the number of emigrants by gender, education, experience, and year. For the baseline specification I use a combination of all data sources, as the census is likely to under-estimate, and the work permit data is likely to over-estimate the number of emigrants. Moreover, only the Irish census contains information on the skill distribution of migrants, while the UK and Irish work permit data only contains information on the inflows per year. Census data from the UK is not available for the time around EU enlargement, as the census was carried out in 2001 and $2011 .^{9}$

7 For further information about PPS and NINO numbers, see http://www.welfare.ie and http://www.direct.gov.uk. In 2004 the UK introduced a Worker Registration Scheme (WRS) for workers from the new member states. Compared to the data from the WRS, NINo offers the advantage that it provides information on immigration before 2004. The WRS and NINo numbers after 2004 are similar.

8 Double counts are only possible if workers received a work permit in both destination countries. Although there does not seem to be any evidence of large numbers of workers registering in both countries, I am aware that double counting could downward-bias the estimates.

$9 \quad$ Other UK datasets, the Labour Force Survey and the European Community Household Panel have few observations on immigrants in each round, and they group immigrants from Eastern Europe by region, not by country. 
To construct measures for the number of emigrants, I take the skill distribution of Lithuanian migrants from the Irish census and multiply it with a weighting factor which accounts for migrants to the UK. The calculation of the share of emigrants is based on the assumption that the skill distribution of Lithuanian immigrants in Ireland is the same as the skill distribution of Lithuanians in the UK. As shown by Elsner (2011), this assumption is justified, as the education and age distribution of migrants from the 8 New Member States in Ireland and in the UK is almost identical. In addition, Hazans and Philips (2009) show that even though migrants from Latvia, Lithuania and Estonia work in different sectors in Ireland and the UK - in Ireland more in construction and trade, in the UK more in agriculture and services - - their education and age profile is the same in both countries.

To make use of all available rounds of the HBS I construct measures for the emigration rates in 2003 and 2005 from the censuses in 2002 and 2006, assuming that the skill distribution of migrants arriving in 2003 is the same as in 2002, and likewise that the skill distribution of migrants in 2005 is the same as in 2006. Table 2 suggests that the education distribution has been constant between 2002 and 2006, which implies that the education distribution has neither changed between 2002 and 2003, nor between 2005 and 2006. The age distribution, on the other hand, has changed between 2002 and 2006; the cohorts arriving after 2002 have been on average younger than the cohorts before 2002 . Nevertheless, given that 2002 and 2003 are both before, and that 2005 and 2006 are both after EU enlargement, so that it is plausible to assume that workers coming in 2003 had roughly the same age distribution as those coming in 2002, and workers arriving in 2005 had the same age distribution as those arriving in 2006.

For $t=(2002,2006)$, the number of emigrants $M_{g h j}^{t}$ is

$$
M_{g h j}^{t}=I E_{g h j}^{t}\left(1+\frac{N I N O_{t}}{P P S_{t}}\right)
$$


$I E_{g h j}^{t}$ is the number of Lithuanians in Ireland in a gender $(g)$-education $(h)$-experience $(j)$ cell at time t. NINOt and PPS are the numbers of British and Irish work permits issued to Lithuanians in year $t$. The first term in parentheses ( 1 in this case), accounts for the number of migrants in the Irish census. The second term, $\frac{N I N O_{t}}{P P S_{t}}$, accounts for migrants to the UK. If, for example, in 2006 the number of work permits in the UK was $50 \%$ higher than the number of work permits in Ireland, this factor is 1.5.

For the year 2003 I take the skill distribution from 2002 and weight it with the inflows of 2003. Analogously, for the year 2005 I use the skill distribution from 2006. The number of emigrants for 2003 and 2005 are

$$
\begin{aligned}
M_{g h j}^{2003} & =I E_{g h j}^{2002}\left(\frac{P P S_{2003}}{P P S_{2002}}+\frac{N I N O_{2003}}{P P S_{2002}}\right) \\
M_{g h j}^{2005} & =I E_{g h j}^{2006}\left(\frac{P P S_{2005}}{P P S_{2006}}+\frac{N I N O_{2005}}{P P S_{2006}}\right) .
\end{aligned}
$$

The first term in parentheses, $\frac{P P S_{2003}}{P P S_{2002}}$ and $\frac{P P S_{2005}}{P P S_{2006}}$ accounts for the changes in inflows between 2002 and 2003, and between 2005 and 2006. ${ }^{10}$ As in Equation (1), the second term in parentheses represents the number of migrants to the UK.

To calculate the emigration rate $m$ per skill group and year I divide the number of emigrants from Equations (1) to (3) by the population in Lithuania of the same group,

$$
m_{g h j t}=\frac{M_{g h j}^{t}}{\sum_{i} p_{g h j t}^{i}} .
$$

The population of skill group $g h j$ in year $t$ is the sum of the sampling weights $p_{\text {ghjt }}^{i}$ of all workers $i$ in the Lithuanian HBS that belong to this group. ${ }^{11}$

\footnotetext{
$10 \quad \frac{N I N O_{2003}}{P P S_{2002}}$ actually consists of two factors: $\frac{N I N O_{2003}}{P P S_{2003}}$, which accounts for the size of migrant flows to the UK relative to Ireland and $\frac{P P S_{2003}}{P P S_{2002}}$, accounting for the change in migration flows to Ireland from 2002 to 2003. By multiplication of those two terms, $P P S_{2003}$ cancels out.

11 The sampling weight $p_{\text {ghijt }}$ is the inverse probability that observation $i$ is included in the sample.
} 
One might be concerned that the calculated emigration rate may over-estimate the actual change in labor supply, in case migrants from other countries had come to Lithuania and taken up the jobs of the workers who left. In fact, the Lithuanian immigration statistics show an increase in the number of immigrants between 2002 and 2006. A closer look, however, indicates that this increase was in large parts driven by return migrants from the UK. ${ }^{12}$

The share of emigrants could also be under-estimated, if workers moved to other countries besides the UK and Ireland, in particular countries close to Lithuania, such as Russia, Germany, and Scandinavia. Of all these countries, however, only the German statistics show a considerable increase in inflows from Lithuania. As shown by Brenke et al. (2009), the annual inflow of Lithuanians increased from 2,775 before EU Enlargement to more than 4,000 from 2004 onwards. Russia, Sweden, Denmark, and Finland did - somewhat surprisingly - not see a large inflow of Lithuanians. Between 200 and 300 migrants annually moved to Russia, Sweden, and Denmark, while the annual inflow in Finland was less than 100. Norway has seen increased immigration from Lithuania in recent years, but the large inflow only occurred after 2007. ${ }^{13}$ In sum, Lithuanians did migrate to countries other than the UK and Ireland, but they moved to these countries in numbers that are small compared to the migration wave to the UK and Ireland.

\section{EMPIRICAL FrameWORK}

The theoretical underpinnings for the empirical strategy are derived from a simple supplyand-demand model of a labor market. Emigration decreases the labor supply, which shifts the labor supply curve inwards. Given a constant, downward-sloping labor demand curve, emigration makes the remaining workers a more scarce resource, and leads to an increase

\footnotetext{
12 Source: Statistics Lithuania.

13 Sources: statistical offices of the respective countries. For Denmark the flows have been calculated from the difference in stocks. Tables can be produced upon request.
} 
in wages.

\subsection{The Skill Group Approach}

To identify the average effect of emigration on wages, I use the skill-group approach proposed by Borjas (2003), which considers emigration rates and wages at the national level and exploits the variation in both variables within skill groups over time. If emigration indeed increased wages, we should observe higher wage increases in groups with a higher share of emigrants.

A skill group is defined by the observable characteristics education and work experience. The workforce consists of 27 skill groups - 3 education and 9 experience groups. The 3 education groups are lower secondary education (at most 10 years of schooling), upper secondary education (11-14 years of schooling), and third-level education (at least 15 years of schooling). ${ }^{14}$

A higher number of education groups would be desirable, as it would allow for more variation in emigration and wages across education groups. The available data, however, imposes a constraint on the number of education groups. The datasets from the sending and receiving countries differ in their classification of education groups; the HBS contains 12, the Irish census only 5 categories. Choosing 3 broad education groups makes it possible to consistently match emigrants and stayers with the same education level.

Each education group is divided into 9 experience groups: 0-4 years, 5-9 years, 1014 years, ..., 40+ years of work experience. The work experience is calculated as the exposure to the labor market, i.e. the time since finishing education, experience $=$ age education - 6 . The value for education is 10 years for lower secondary, 12 years for upper secondary, and 15 years for third-level education.

14 See Appendix C.2 for a detailed description of the educational tracks. 


\subsection{EMPIRICAL MODEL}

The empirical model is a regression of individual wages on the share of emigrants in the individual's skill group, estimated from pooled cross-sectional data. The baseline estimating equation is

$$
w_{g h t}^{i}=\delta m_{g h t}+\boldsymbol{X}_{\boldsymbol{g h t}}^{\boldsymbol{i}^{\prime}} \boldsymbol{\beta}+\text { year }+ \text { educ }+ \text { exper }+\varepsilon_{g h t}^{i} .
$$

$w_{g h t}^{i}$ is the $\log$ real wage of individual $i$ with education $g$, experience $h$ in year $t=$ $2002,2003,2005,2006$. $m_{g h t}$ is the emigration rate for individual i's skill group. The coefficient of interest, $\delta$, denotes the percentage change in real wages associated with a 1 percentage-point change in the emigration rate.

The dummy variables year, educ, and exper absorb changes in average wages over time, and differences in average wages across education and experience groups. $\boldsymbol{X}_{\boldsymbol{g h t}}^{\boldsymbol{i}}$ is a vector of individual control variables, which include gender, marital status, whether individual $i$ has children under 18, and whether she lives in a city. $\varepsilon_{g h t}^{i}$ is an error term. Because $m_{g h t}$, the regressor of interest, is a group variable defined by education, experience and time, I cluster the standard errors at the year, education, and experience level.

The model in Equation (5) has the advantage that it uses a low number of degrees of freedom, but it potentially comes at the cost of omitted variable bias. The year, educ, and exper dummies reduce this bias, but there could be factors that have an impact on wages over and above what is absorbed by the dummies. Examples are changes in the returns to education or experience, or demand shifters such as FDI or exports. To account for these factors, I extend the baseline model with the interaction terms (year *educ), $($ year $*$ exper $)$, and $($ educ * exper $)$. (year * educ) and (year * exper) absorb changes in 
the returns to education and experience; (educ*exper) accounts for differences in the age-earnings profile across education groups.

The inclusion of interaction terms has the additional advantage that it absorbs crosswage effects. If the underlying theoretical model has a heterogeneous workforce with several skill groups, the impact of emigration depends on the demographic characteristics of the emigrants compared to the stayers (Card and Lemieux, 2001; Borjas, 2003). Emigration in one skill group affects the marginal product of all other groups, and has a larger wage impact on groups that are close substitutes. After controlling for cross-wage effects, $\delta$ measures the own-wage effect, i.e. the average effect of the emigration of workers from a specific skill group on the wages of that same group.

\subsection{IDENTIFICATION ISSUES}

\subsubsection{SOURCES OF VARIATION: SKILL GROUPS VS. OCCUPATIONS VS. GEOGRAPHY}

The skill-group approach overcomes identification problems inherent in the migration literature, by focusing on migration and wages at the national level. A large number of studies have used geographic variation of migration and wages to identify the impact of immigration on the wages of natives. ${ }^{15}$ The small and insignificant effect typically found in these studies can be the result of unobserved adjustment in local labor markets or of the endogenous location choice of migrants. If migrants locate in areas with more flexible labor markets, they may be absorbed without depressing the wages of natives, or immigration can trigger the outflows of natives (Card, 2001). In addition, if migrants locate in areas that experience an economic boom and high wages, a spurious positive correlation between the share of immigrants and wages may appear. The skill group

$15 \quad$ See Friedberg and Hunt (1995) and Kerr and Kerr (2011) for a review of this literature and Longhi et al. (2010) for a meta-analysis. 
approach, by contrast, eliminates the endogeneity in the location choice of migrants. Endogeneity bias could only arise if migrants were able to choose their skill group, but this is not possible as workers generally make their education decision before they enter the workforce.

Some studies overcome the bias resulting from endogenous location choice by exploiting variation in migration rates and labor market outcomes within occupations at the national level (Card, 2001; Friedberg, 2001). If the occupation is predetermined by the immigrants' education and training, and if immigrants cannot easily switch to occupations with higher wage growth, it is possible to estimate a causal effect of immigration on wages and employment.

Although the within-occupations approach can provide a clean identification, it requires information on the occupation before emigration, which is not available for Lithuanian workers in Ireland and the UK. The only available information is the migrants' current occupation after emigration. In the context of EU enlargement, however, it is not possible to use this information to infer the occupation before emigration. As shown by Kahanec et al. (2009, p. 20), Drinkwater et al. (2009) and Saleheen and Shadforth (2006), immigrant workers from the new member states were overrepresented in typical low-skilled occupations, although their education level was on average higher than the level of natives. The skill group approach, by contrast, clusters the workforce in broader categories and makes emigrants and stayers comparable.

\subsubsection{ENDOGENEITY ISSUES}

The marginal effect of emigration on wages only has a causal interpretation if emigration is exogenous. Ideally, one would run an experiment, in which the emigration rate is randomly assigned across skill groups. After controlling for all other factors in Equation (5), the average change in wages could then be exclusively attributed to emigration. As 
reality does not permit such experiments, identification has to rely on quasi-experimental variation in emigration rates.

Identification in this study is based on an exogenous change in migration laws after the EU accession of Lithuania in 2004. Only when the country joined the European Union were workers actually allowed to emigrate and take advantage of the higher wages in Western Europe. As Figure 1 shows, few Lithuanians migrated to Ireland and the UK before 2004, while the large migration wave began in 2004. Using the variation in emigration rates and real wages within skill groups from 2002 to 2006, the model in Equation (5) compares the emigration rates and wages for each skill group in the two years before and the two years after EU accession. The increase in emigration rates was caused by an exogenous policy change. Therefore, the changes in real wages, over and above the dummies and interaction terms, can be attributed to emigration.

A potential concern about the exogeneity of EU enlargement is that workers could have anticipated the lifting of migration barriers and accumulated destination-specific human capital. In the lead-up to EU enlargement, workers in Lithuania could have indeed anticipated that they were allowed to emigrate, as the country began its accession negotiations in 1999. Yet the destinations for migration only became clear in 2003, when the old member states decided on temporary restrictions of their labor markets. Germany, for example, only decided in spring 2004 that it would keep its labor markets closed for workers from the new member states (Deutscher Bundestag, 2004).

While in theory the causality runs from migration to wages, the direction of causality is less clear empirically. Wages can be a push factor for migration, as low wages create an incentive for workers to emigrate. In this case the relation between migration and wages should be negative, as skill groups with low wages should have high emigration rates. In the Lithuanian case, however, reverse causality should not confound the results. The emigration wave was triggered by the country's EU accession, and workers from all skill 
groups emigrated despite considerable wage increases. Moreover, if the estimate of $\delta$ is positive, reverse causality can at most downward-bias the result.

Equation (5) only identifies the wage effect if labor demand is constant. Shifts of the labor demand curve, unless controlled for, can bias the estimates. One such demand shifter is capital adjustment. Based on the idea of a Solow (1956)-type framework, emigration leads to a decrease in the capital stock, which offset the wage effect of emigration in the long run. This paper, by contrast, studies a short-run effect, so that capital adjustments should not affect the results. Moreover, it is unlikely that firms decrease their capital stock in a period of high economic growth, as Lithuania experienced in the 2000s.

One might be concerned that the Lithuanian economy underwent structural changes around the time of EU enlargement In particular, EU enlargement did not only change the migration laws; Lithuania gained access to a free-trade area and received EU structural funds, which may cause an increase in labor demand. If EU enlargement changed the trade and investment patterns, we would expect a shift in the level of exports and FDI, or a change in the trend of both variables. The aggregate data does not suggest that EU accession has led to substantial shifts in the trade and investment patterns. As we can see in Figure 2, none of these variables shows a structural break after EU enlargement. ${ }^{16}$

\section{[Figure 2 about here]}

The overall time trend in the trade and investment patterns - and of other factors that affect wages, such as TFP growth - is accounted for by the year dummies in Equation (5). In addition, if a factor shifts labor demand for high-skilled workers more than

16 Between 2004 and 2006 Lithuania received EU structural funds of EUR 1.5bn, which is $8 \%$ of the country's real GDP in 2004. The largest share of the funds, which were spread across 3,500 projects, went into infrastructure projects (European Commission, 2007). 
for low-skilled workers, or for young workers more than for old workers, the interactions $(y e a r * e d u c)$ and (year*exper) absorb these differential demand shifts. The only demand shifts I cannot control for with interaction terms, are skill group-specific demand shifts, because an interaction (year * educ* exper) would completely saturate the model.

\subsubsection{SELF-SELECTION OF MIGRANTS}

As it is only possible to observe the wages of workers who decide not to migrate, selfselection arises as a potential source of bias.

Negative self-selection of migrants leads to an upward-bias in the estimates. If most emigrants are selected from the lower end of the wage distribution, the average wage of the remaining workers increases. Yet, this increase is not caused by a decrease in labor supply, but by a change in the composition of the workforce. Analogously, if most emigrants are selected from the upper end of the wage distribution, the estimates will be downward-biased.

The selection of migrants can occur along two dimensions: between and within skill groups. When we compare the education distribution of stayers in Table 1 and of migrants in Table 2, we can see that, between skill groups, emigrants were negatively selected. Negative selection, however, does not bias the results, as the dummies and interaction terms in Equation (5) account for it.

Selection within skill groups - a selection pattern that can not be observed from the summary statistics - can be a source of bias. It is difficult to determine the direction and size of this bias, as the data has no information on counterfactual wages, i.e. the wages emigrants would earn had they stayed in Lithuania. The standardized wage distribution in Lithuania before and after EU enlargement does not give evidence of selection bias. If migrants were on average negatively selected, we would expect the probability mass to shift to the right. As we can see in Figure 3, the shape of the wage distribution is almost 
identical in 2002 and 2006. ${ }^{17}$

\section{[Figure 3 about here]}

Moreover, given the difference in the economic situation between Lithuania and Ireland and the UK, it is unlikely that migrants are on average negatively selected. First, migrants are, by definition, more mobile than stayers. If mobility is positively correlated with ability, migrants should be on average more skilled than stayers, and earn higher wages.

Second, because of the foreign language requirements, and because of minimum wages, the skill requirements are on average higher in the UK and in Ireland than in Lithuania. Most jobs, in particular in the service sector, require fluency in English and a good knowledge of British or Irish culture. In addition, the minimum wages in the UK and Ireland are considerably higher than in Lithuania, which creates an additional hurdle for low-skilled migrants. Only the more productive migrants get a job that pays them at least the minimum wage. ${ }^{18}$ As the UK Home Office (2009) shows, more than $80 \%$ of immigrants from the accession countries were officially employed, so that the minimum wage is binding for the majority of immigrants.

Third, since there was little migration from Lithuania to Ireland and the UK prior to EU accession, migrants could not rely on large migrant networks that would support them in finding a job and facilitate assimilation. As suggested by the literature on migrant networks (Carrington et al., 1996; McKenzie and Rapoport, 2010), small networks are usually associated with a positive selection of migrants.

\footnotetext{
$17 \quad$ Figure 4 in Appendix C.4 plots separate wage distributions for men and women. For men, there have been some changes to the left of the mean, but no substantial shifts in the probability mass. By contrast, for women the probability mass moved to the left of the mean, indicating a positive selection.

18 In 2004, minimum wages were EUR 7 in Ireland and GBP 4.85 in the UK.
} 
Closely related to the issue of self-selection is the question whether some of the workers were unemployed before they emigrated. If this was the case, emigration could have decreased unemployment and — in the most extreme case — have no effect on wages. In fact, Figure 2 shows that unemployment had been falling between 2002 and 2006 . While I cannot exclude that emigration played a role in reducing unemployment, the unemployment rate does not show a structural break after EU accession. Even the emigration of $9 \%$ of the workforce did not cause a sudden drop in the unemployment rate.

If being unemployed is associated with lower ability, and if migrants are on average positively selected within skill groups, then most of the migrants should be employed at the time of emigration. While the Lithuanian unemployment data is not detailed enough to calculate unemployment rates per skill group, it is possible to control for unemployment at the regional level, which I do in a robustness check in Appendix C.1. Moreover, for the unlikely case that many emigrants were unemployed right before emigration, the estimates of the wage effect would be downward-biased, as the calculated emigration rate would be higher than the actual one.

\section{EMPIRICAL ANALYSiS}

\subsection{Estimation RESUlts}

Table 3 presents the results of the estimated impact of emigration on the real wages of stayers. The wage effect for men and women, reported in Column (1), indicates that emigration predicts a significant increase in wages. A one percentage-point increase in the emigration rate increases real wages on average by $0.67 \%$.

\section{[Insert Table 3 here]}


While this effect may be large and statistically significant on average, the wage effects can differ between men and women. To analyze the difference in the wage effect between men and women, I interact the emigration rate with a dummy for men. As column (2) shows, the coefficient of the interaction term indicates a large and statistically significant difference in the wage effect of emigration for men and women. For a one percentage-point increase in the emigration rate, the wages of men increased on average by $1.1 \%$, while the marginal effect for women is smaller and statistically insignificant. From columns (5) and (6) we can see that these results also hold if the sample is split between men and women.

In Column (3) I control for FDI inflows, exports, and unemployment at the regional level. Each of these factors can confound the analysis, if they affect wages over and above what it absorbed by the dummy variables. The three variables are measured at the regional level, so that the wage of a person can be matched with the FDI, unemployment, and exports in the region the person is living in. It is reassuring that the most obvious potential confounding factors, FDI, exports, and unemployment, do not change the results of the more parsimonious specification in Column (1).

Next, I include an interaction of region and year dummies into the basic model to ensure that no other factors affect wages at the regional level. The region*year interactions absorb all economic factors that affect a region over time but are unrelated to emigration. The results of this specification, displayed in Column (4), are not different from the previous result.

\section{[Insert Table 4 here]}

An obvious problem with controls at the regional level is that the demand shifters are the same for all skill levels. If, for example, the demand shift is larger for high-skilled 
than for low-skilled workers, this change in returns to education cannot be captured with the controls of the basic model. To account for changes in returns to education, I reestimate the basic model with an interaction of year and education dummies. As we can see in Column (1) of Table 4, the estimated wage effect is the same when we account for changes in returns to education.

In a similar fashion, the returns to experience can change over time. Technological progress, for example, can benefit young workers more than old workers. To account for changes in returns to experience, I include an interaction of year and experience dummies. Column (2) of Table 4 indicates that changes in returns to education explain part of the wage increases. The point estimates are 0.3 lower compared to the benchmark case.

Part of the initial results can also be driven by differences in the age-earnings profile across education groups. The basic model in Equation (5) estimates a separate intercept for every education level, every experience level, and every year. The difference in wages for old and young workers, however, may be larger for high-skilled workers than for low-skilled workers, or vice versa. An interaction of education and experience dummies absorbs the difference in the age-earnings profile between education groups. The results in Column (3) of Table 4 suggest that the age-earnings profiles differ in fact by education level. Taking them into account increases the point estimates for men and women by 0.3 .

The inclusion of interaction terms changes the estimates, which suggests that returns to education, returns to experience, and difference in age-earnings profiles explain part of the wage changes. To see how the interactions jointly affect the results, I include two interactions at a time in Columns (4)-(6) in Table 4. The results are mixed, with results similar to the baseline case in Columns (5) and (6), and no statistical significance and low point estimates if year*education and year*experience are included. Column (7) displays the estimates with all three interactions included. In this specification - the same as in Borjas (2003) and Mishra (2007) - the only possible variation is within skill groups over 
time. Despite the large number of regressors, I find a large and statistically significant positive effect of emigration on the wages of men, and a statistically insignificant effect on the wages of women.

\subsection{DISCUSSION OF THE RESUlTS}

The results show that emigration has a positive impact on wages on average, which is consistent with a supply-and-demand framework. Emigration leads to labor shortages, which — given a downward-sloping labor demand curve - causes an increase in real wages. EU enlargement increased the workers' bargaining power vis-a-vis their employers, which enabled them to negotiate higher wages.

The estimated effect is statistically and economically significant. The marginal effect of 0.67 means that a one percentage-point increase in the emigration rate increases real wages on average by $0.67 \%$, which is in line with Elsner (2011), who estimates the demand elasticity with the same data in a structural model. If $5 \%$ of the Lithuanian workforce emigrated permanently, the model predicts that wages increase by $3.3 \%$ over 5 years. Given average wages in Lithuania increased by $40 \%$ over the same period (see Table 1), emigration can explain $8 \%$ of the overall wage increases. If we focus on the marginal effect for men, emigration even explains $16 \%$ of the wage increases.

The difference in the wage effects for women and men is striking. There are several potential explanations for the absence of a significant effect for women.

One explanation is female labor force participation. The data from the UK and Ireland may over-estimate the number of women that have left the Lithuanian workforce, because either the emigrant women were not part of the workforce, or because they were replaced by women who were previously not part of the workforce. In both cases the actual number of emigrants would be smaller than the number in the British and Irish data and we could expect a lower impact of migration on wages. Yet given that throughout the 
2000s female labor force participation has been as high as the participation of men, this explanation seems less plausible.

The differential effect could perhaps be due to the sectoral composition of emigration, if women are over-represented in sectors with more rigid wages. While the data on emigrants does not yield any information on the migrants' occupation prior to migration, we can at least look at the share of women working in different sectors in Lithuania. In the 2000s women were over-represented in services, while men were over-represented in agriculture, construction, and manufacturing. The earnings increases for services, however, were similar to the increases construction, and were larger than in manufacturing and agriculture. In sum, the sectoral composition cannot explain the difference in the wage effects. ${ }^{19}$

Another explanation could be that EU enlargement gave a higher bargaining power to men than to women. If men are the main earners of the family, it is easier for men than for women to use the option to emigrate as a credible threat when negotiating their salaries.

Yet another explanation is self-selection of emigrant women. If women were on average selected from the upper end of the wage distribution then the average wage of the remaining women decreases. The shift of the wage distribution, shown in Figure 4 in the online appendix, supports this explanation.

\section{ConClusion}

In this paper I study the effect of emigration on the wages of stayers. According to a simple supply-and-demand framework, emigration reduces labor supply and causes an increase in real wages. Using the emigration wave from Lithuania after EU enlargement, I test this hypothesis.

19 Sources: Statistics Lithuania. Table available on request. 
With EU enlargement, workers from Lithuania were allowed to emigrate to the UK and Ireland; around $9 \%$ of the Lithuanian workforce emigrated after the country joined the European Union. I exploit this exogenous change in migration laws and the resulting emigration wave to identify the effect of emigration on wages, using variation within demographic groups over time. The estimated impact of emigration on wages is significant. A one-percentage point increase in the emigration rate increases real wages on average by $0.66 \%$. This effect, however, is only significant for men, not for women. The magnitude of the effect is larger than in previous studies (Mishra, 2007; Aydemir and Borjas, 2007), which looked at the long-run effect. The results of this study indicate that emigration can have a larger effect in the short run than in the long run

The results can inform policymakers about the effects of a large emigration wave on the labor markets in the sending countries. There are a number of middle-income countries that could face a similar emigration wave, once their workers are allowed to emigrate. Examples are EU candidate countries like Croatia, Serbia, Montenegro, or Turkey, which exhibit large wage differentials vis-á-vis Western Europe.

This study opens several avenues for future research. As more migration data becomes available, it is important to check the validity of the results for a larger number of countries. While the immigration literature has found very small effects of migration on wages in the receiving countries, the limited evidence on the sending countries shows that the effects can be significant. To be certain that this effect is not only limited to a small number of countries, we require evidence from more countries.

EU enlargement occurred during an economic boom in Western Europe so that workers from Eastern Europe could easily find jobs after emigration. With the financial crisis, starting in 2008, the prospects for migrants in most of Western Europe have become less positive, and many migrants are returning to their home countries. These two states of the European economy - boom before 2008, followed by a crisis - could be used to 
identify to what degree migration and return migration is driven by wage differentials and differences in the employment rates. Moreover, in looking at workers that emigrated immediately after EU enlargement it would be interesting to investigate which workers stayed and which workers returned to their home countries, and what determined the timing of the decision to return. 


\section{REFERENCES}

Aydemir A, Borjas G (2007) Cross-Country Variation in the Impact of International Migration: Canada, Mexico and the United States. Journal of the European Economic Association 5(4):663-708

Barrell R, FitzGerald J, Riley R (2010) EU Enlargement and Migration: Assessing the Macroeconomic Impacts. Journal of Common Market Studies 48(2):373-395

Barrett A (2009) EU Enlargement and Ireland's Labour Market. In: Kahanec M, Zimmermann KF (eds.) EU Labor Markets after Post-Enlargement Migration, Springer-Verlag, Berlin. 145-161

Bauer TK, Zimmermann KF (1999) Assessment of Possible Migration Pressure and its Labour Market Impact Following EU Enlargement to Central and Eastern Europe. IZA Research Report 3

Blanchflower DG, Shadforth C (2009) Fear, Unemployment and Migration. The Economic Journal 119:136-182

Boeri T, Brücker H (2001) Eastern Enlargement and EU-Labour-Markets. World Economics 2(1):49-68

Borjas GJ (2003) The Labor Demand Curve IS Downward Sloping: Re-examining the Impact of Immigration on the Labor Market. The Quarterly Journal of Economics 118(4):1335-1374

Bouton L, Paul S, Tiongson ER (2011) The Impact of Emigration on Source Country Wages: Evidence from the Republic of Moldova. Worldbank Policy Research Working Paper 5764 
Brenke K, Yuksel M, Zimmermann KF (2009) EU Enlargement under Continued Mobility Restrictions: Consequences for the German Labor Market. In: Kahanec M, Zimmermann KF (eds.) EU Labor Markets After Post-Enlargement Migration, Springer-Verlag

Card D (2001) Immigrant Inflows, Native Outflows and the Labor Market Impact of Higher Immigration. Journal of Labor Economics 19(1):22-64

Card D, Lemieux T (2001) Can Falling Supply Explain the Rising Return to College For Younger Men? A Cohort-Based Analysis. The Quarterly Journal of Economics 116(2):705-46

Carrington WJ, Detragiache E, Vishwanath T (1996) Migration with Endogenous Moving Costs. The American Economic Review 86(4):909-930

Clemens MA (2011) Economics and Emigration: Trillion-Dollar Bills on the Sidewalk? Journal of Economic Perspectives 25(3):83-106

Constant AF (2011) Sizing it up: Labor Migration Lessons of the EU Enlargement to 27. IZA Discussion Paper 6119

Deutscher Bundestag (2004) Entwurf eines Gesetzes über den Arbeitsmarktzugang im Rahmen der EU-Erweiterung. Drucksache 15/2672

Drinkwater S, Eade J, Garapich M (2009) Poles Apart? EU Enlargement and the Labour Market Outcomes of Immigrants in the UK. International Migration 47(1):161-190

Elsner B (2011) Emigration and Wages: The EU Enlargement Experiment. IZA Discussion Paper 6111

European Commission (2007) The European Structural Funds (2004-2006), Lietuva

Friedberg RM (2001) The Impact of Mass Migration on the Israeli Labor Market. The Quarterly Journal of Economics 116(4):1373-1408 
Friedberg RM, Hunt J (1995) The Impact of Immigration on Host Country Wages, Employment and Growth. Journal of Economic Perspectives 9(2):23-44

Gagnon J (2011) "Stay with Us?" The Impact of Emigration on Wages in Honduras. OECD Working Paper 300

Hazans M, Philips K (2009) The Post-Enlargement Migration Experience in the Baltic Labor Markets. In: Kahanec M, Zimmermann KF (eds.) EU Labor Markets after Post-Enlargement Migration, Springer-Verlag, Berlin. 255-304

Home Office (2009) Accession Monitoring Report, May 2004-December 2008, A8 Countries. Home Office Report

Kaczmarczyk P, Mioduszewska M, Zylicz A (2009) Impact of the Post-Accession Migration on the Polish Labor Market. In: Kahanec M, Zimmermann KF (eds.) EU Labor Markets after Post-Enlargement Migration, Springer-Verlag, Berlin. 219-253

Kahanec M, Zaiceva A, Zimmermann KF (2009) Lessons from Migration after EU Enlargement. In: Kahanec M, Zimmermann KF (eds.) EU Labor Markets after PostEnlargement Migration, Springer-Verlag, Berlin. 3-45

Kahanec M, Zimmermann KF (eds.) (2009) EU Labor Markets After Post-Enlargement Migration. Springer-Verlag, Berlin

Kerr SP, Kerr WR (2011) Economic Impacts of Immigration: A Survey. Finnish Economics Papers 24(1):1-32

Longhi S, Nijkamp P, Poot J (2010) Joint impacts of Immigration on Wages and Employment: Review and Meta-Analysis. Journal of Geographical Systems 12:355-387

McKenzie D, Rapoport H (2010) Self-Selection Patterns in Mexico-U.S. Migration: The Role of Migration Networks. Review of Economics and Statistics 92(4):811-821 
Mishra P (2007) Emigration and Wages in Source Countries: Evidence from Mexico. Journal of Development Economics 82:180-199

Saleheen J, Shadforth C (2006) The Economic Characteristics of Immigrants and Their Impact on Supply. Bank of England Quarterly Bullettin Q4:373-385

Sinn HW (2004) EU Enlargement, Migration, and the New Constitution. CESifo Working Paper 1367

Solow RM (1956) A Contribution to the Theory of Economic Growth. The Quarterly Journal of Economics 70(1):65-94

Wadensjö E (2007) Migration to Sweden from the New EU Member States. IZA Discussion Paper 3190

Zaiceva A, Zimmermann KF (2008) Scale, Diversity and Determinants of Labour Migration in Europe. Oxford Review of Economic Policy 24(3):428-452 
A Tables 
Table 1 - Summary Statistics Lithuania

\begin{tabular}{|c|c|c|c|c|}
\hline & 2002 & 2003 & 2005 & 2006 \\
\hline \multicolumn{5}{|l|}{ a) Lithuanian HBS } \\
\hline men & 2,322 & 2,411 & 2,426 & 2,314 \\
\hline women & 1,628 & 1,725 & 1,616 & 1,560 \\
\hline \multicolumn{5}{|l|}{ Education } \\
\hline lower secondary & $8.81 \%$ & $10.42 \%$ & $10.76 \%$ & $9.91 \%$ \\
\hline upper secondary & $69.01 \%$ & $69.17 \%$ & $67.62 \%$ & $67.48 \%$ \\
\hline third-level & $22.18 \%$ & $20.41 \%$ & $21.62 \%$ & $22.61 \%$ \\
\hline \multicolumn{5}{|c|}{ Monthly Earnings (LTL) } \\
\hline men & $\begin{array}{l}1,185 \\
(856)\end{array}$ & $\begin{array}{l}1,252 \\
(913)\end{array}$ & $\begin{array}{l}1,440 \\
(981)\end{array}$ & $\begin{array}{r}1,688 \\
(1,134)\end{array}$ \\
\hline women & $\begin{array}{r}940 \\
(684)\end{array}$ & $\begin{array}{r}988 \\
(686)\end{array}$ & $\begin{array}{l}1,189 \\
(890)\end{array}$ & $\begin{array}{l}1,303 \\
(985)\end{array}$ \\
\hline
\end{tabular}

\section{b) Lithuanian Statistical Office}

Monthly Earnings (LTL)

\begin{tabular}{lrrrr} 
men & 1,173 & 1,227 & 1,420 & 1,676 \\
women & 998 & 1,029 & 1,167 & 1,356 \\
\hline
\end{tabular}

Note: a): Summary statistics for all employees between 18 and 64 years. Education groups: lower secondary education (10 years or less of schooling), upper secondary education (more than 10 years of schooling, but no finished third-level education), third-level degree (at least 15 years of schooling and B.Sc equivalent). Percentages of educational distribution relative to all men and women in a given year. Monthly earnings are deflated by the HCPI. Standard errors of monthly earnings in parentheses.

b) monthly earnings are average gross monthly real earnings in LTL. 


\section{Table 2 - Summary Statistics, Irish Census}

$\begin{array}{crrr} & \text { 2002 } & & \text { 2006 } \\ \text { Observations } & & \\ \text { men } & 978 & & 12,085 \\ \text { women } & 904 & & 9,293\end{array}$

Education

$\begin{array}{lrr}\text { lower secondary } & 16.6 \% & 20.1 \% \\ \text { upper secondary } & 63.4 \% & 62.3 \% \\ \text { third-level } & 20.0 \% & 17.56 \%\end{array}$

\begin{tabular}{crr}
\multicolumn{1}{l}{ Age } & \\
$<20$ & $3.5 \%$ & $2.8 \%$ \\
$20-29$ & $53.3 \%$ & $60.7 \%$ \\
$30-39$ & $26.0 \%$ & $24.6 \%$ \\
$40-49$ & $23.3 \%$ & $9.4 \%$ \\
$50+$ & $3.9 \%$ & $2.5 \%$ \\
\hline
\end{tabular}

Note: This table displays the summary statistics of the Irish census. Education groups: lower secondary education (10 years or less of schooling), upper secondary education (more than 10 years of schooling, but no finished third-level education), third-level degree (at least 15 years of schooling and B.Sc equivalent). Percentages of education and age distribution relative to all men and women in a given year. 
TABle 3 - The Wage effect of Emigration

Dependent variable: log real wage

\begin{tabular}{|c|c|c|c|c|c|c|}
\hline Sample: & $\begin{array}{l}(1) \\
\text { all }\end{array}$ & $\begin{array}{l}(2) \\
\text { all }\end{array}$ & $\begin{array}{l}(3) \\
\text { all }\end{array}$ & $\begin{array}{l}(4) \\
\text { all }\end{array}$ & $\begin{array}{l}(5) \\
\text { men }\end{array}$ & $\begin{array}{c}(6) \\
\text { women }\end{array}$ \\
\hline Emigration rate & $\begin{array}{c}0.665^{* *} \\
{[0.2937]}\end{array}$ & $\begin{array}{c}0.391 \\
{[0.3132]}\end{array}$ & $\begin{array}{c}0.426 \\
{[0.3154]}\end{array}$ & $\begin{array}{c}0.401 \\
{[0.3236]}\end{array}$ & $\begin{array}{c}1.245^{* * *} \\
{[0.2950]}\end{array}$ & $\begin{array}{c}0.283 \\
{[0.3910]}\end{array}$ \\
\hline Emigration $*$ male & & $\begin{array}{c}0.799 * * * \\
{[0.2936]}\end{array}$ & $\begin{array}{c}0.793^{* * *} \\
{[0.2912]}\end{array}$ & $\begin{array}{c}0.777^{* * *} \\
{[0.2852]}\end{array}$ & & \\
\hline Year dummies & yes & yes & yes & yes & yes & yes \\
\hline Education dummies & yes & yes & yes & yes & yes & yes \\
\hline Experience dummies & yes & yes & yes & yes & yes & yes \\
\hline FDI, unemp., exports & no & no & yes & no & no & no \\
\hline Year $*$ region & no & no & no & yes & no & no \\
\hline Observations & 9970 & 9970 & 9970 & 9970 & 6771 & 3199 \\
\hline Adjusted $R^{2}$ & 0.3463 & 0.3468 & 0.3568 & 0.3638 & 0.3371 & 0.3222 \\
\hline
\end{tabular}

Note: This table shows the OLS results for the econometric model in Equation (5), a regression of log real wages on the emigration rate, interactions of the emigration rate with a dummy for men (emig*male), a vector of personal characteristics.

Standard errors are clustered at the time-education-experience level. All observations are weighted with survey weights.

FDI stocks (in logs), unemployment rate and exports (in logs) are measured at the regional level. Year*region is an interaction of year and region dummies. 


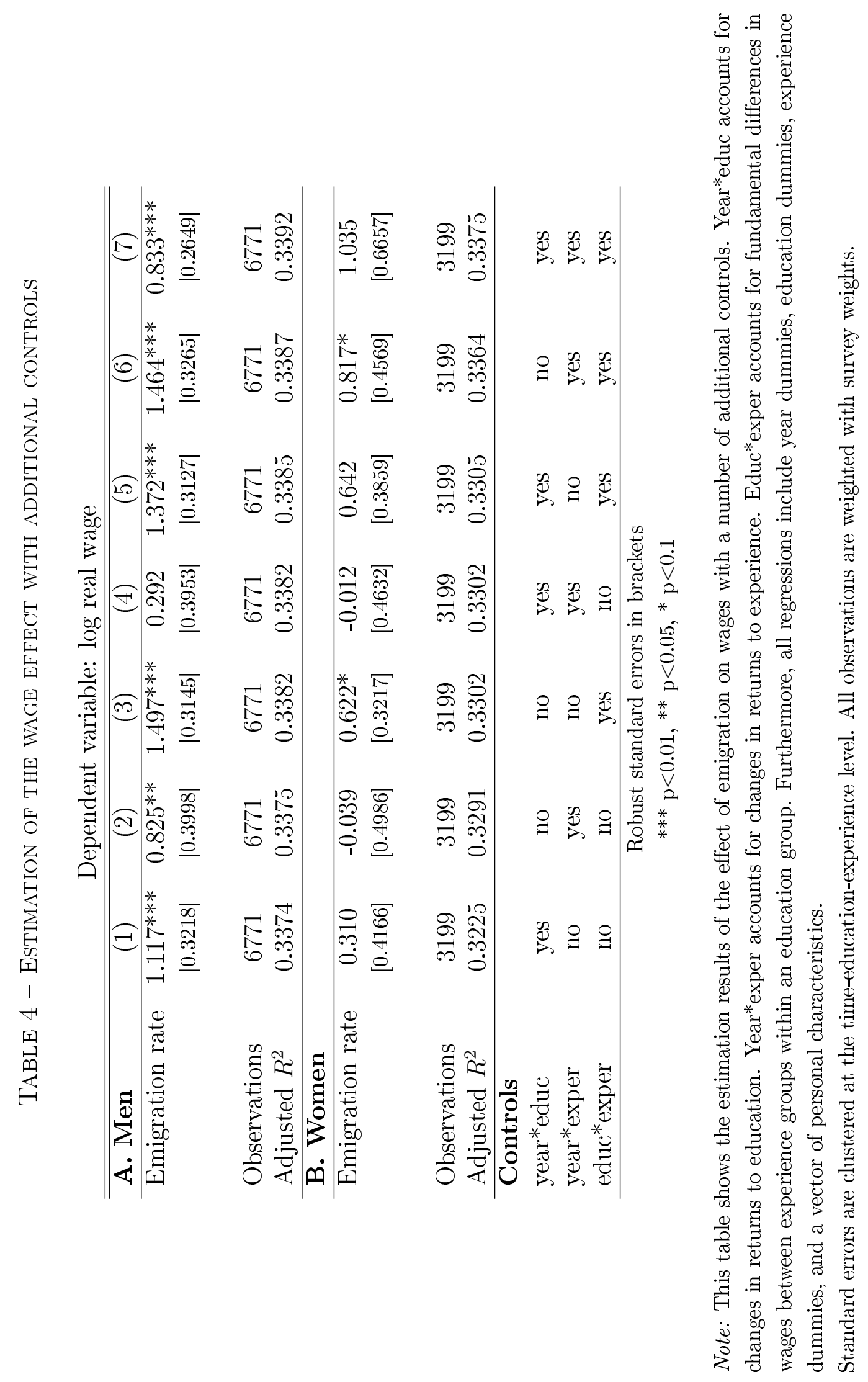




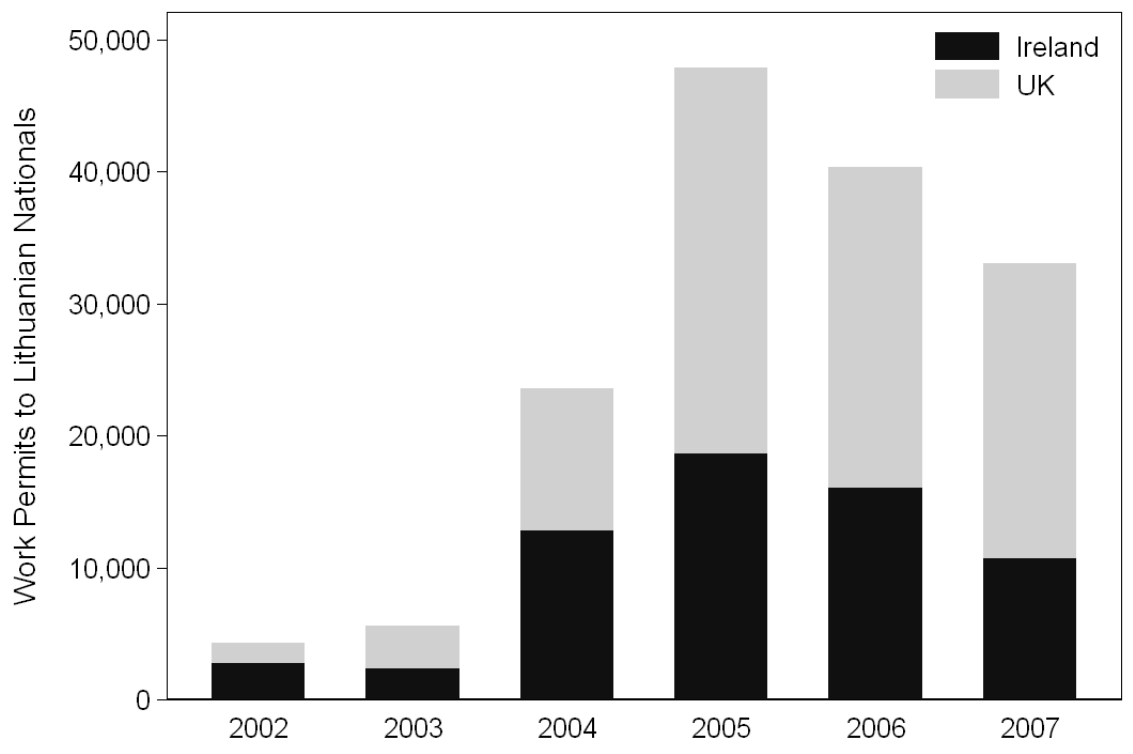

Figure 1 - Lithuanian Immigrants to the UK and Ireland, 2002-2007

Notes: Number of Lithuanian immigrants to the UK and Ireland between 2002 and 2007, as measured by the number of work permits (PPS Number in Ireland, National Insurance Numbers in the UK).

Sources: Irish Department of Social and Family Affairs, UK Department for Work and Pensions.

\section{B Figures For the Body of THE PAPER}




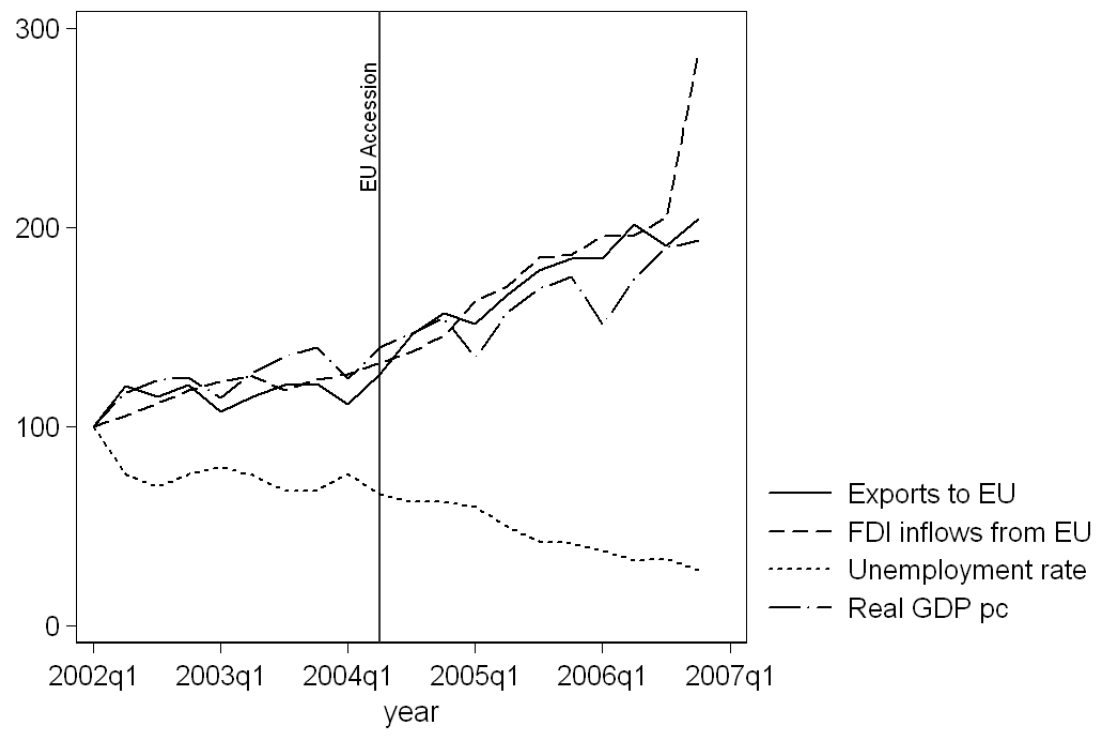

Figure 2 - FDI, EXPorts, GDP PER CAPiTA, AND THE UnEMPLOYMENT RATE IN LithuAnia, 2002-2006

Notes: The graph shows the time series for exports to the EU, FDI inflows from the EU, real GDP per capita and the unemployment rate. All variables are normalized to 100 (first quarter in 2002). None of the variables shows a structural break around EU enlargement.

Source: Statistics Lithuania 


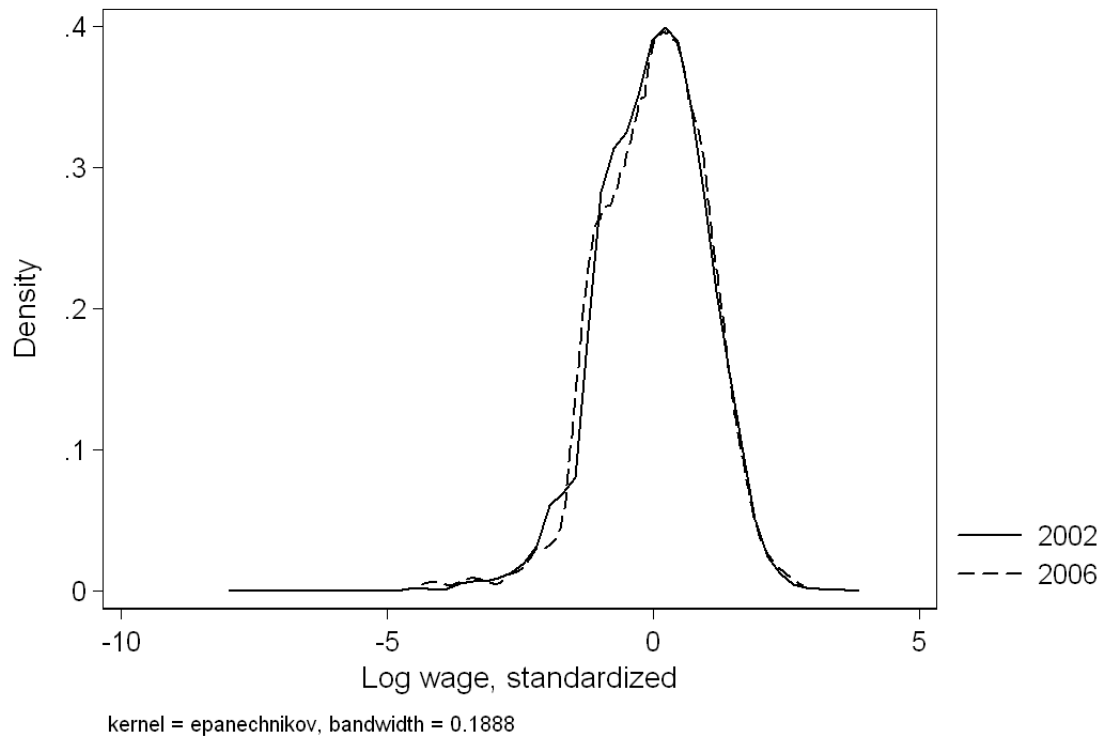

Figure 3 - Standardized Wage distribution in Lithuania, 2002 and 2006

Notes: The graph shows a Kernel density plot of the log real wages in 2002 and 2006. This plot allows for a comparison of the wage distribution before and after EU accession. It shows that the shape of the distribution has only changed slightly, despite the emigration of $9 \%$ of the workforce.

To make the distribution comparable across years, wages are standardized to their z-scores, i.e. the wage of an individual minus the mean wage, divided by the standard deviation of wages, $z_{i}=\left(w_{i}-\bar{w}\right) / \sigma_{w}$. The mean of the distribution is zero. Source: Lithuanian Household Budget Survey 


\section{Online Appendix}

\section{C.1 Robustness CheCKS}

The calculation of the emigration rates is based on a number of assumptions. Table 5 demonstrates how the results change when the assumptions are dropped. Panel A) shows the results for the baseline model in Equation (5); in panel B) I add a rich set of interaction terms. Columns 1) and 2) show the sensitivity of the results with respect to changes in the cell size. The coefficients are lower for 2-year cells and larger for 10-year cells. Panel i) displays the estimates for men and women together. The coefficient is statistically significant for 2-year cells but not for 5-year cells. The statistical significance of the effect for men is not affected by the cell size.

In Column 3) I drop the data for 2003 and 2005, as I do not have precise emigration data for these years. We first look at panel A): The coefficient for men and women jointly is larger than in the baseline and statistically significant at the $5 \%$ level. The interaction of the emigration rate and the male dummy in ii) is similar to the baseline, and significant at the $10 \%$ level. In the saturated model in panel B) none of the coefficients is statistically significant.

Column 4) displays the results for Irish data only. This exercise clearly underestimates the number of emigrants, as around $60 \%$ of all Lithuanian emigrants went to the UK. As a consequence, the coefficients are significantly larger than in the baseline scenario.

\section{[Insert Table 5 here]}




\section{C.2 Education Groups}

The Lithuanian education system offers a variety of educational tracks and degrees. ${ }^{20} \mathrm{I}$ aggregate the different education levels into three broad education groups for two reasons: Firstly, the Irish census only includes five different education groups (primary and lower, lower secondary school, upper secondary school, third-level - no degree and third-level degree), so that a matching of the educational attainment of emigrants and stayers is only possible if broader education groups are considered. Secondly, in some cases different educational tracks in Lithuania lead to comparable degrees. For example, the basic school, which students finish at the age of 16 , and the stage I of vocational training. Both of those tracks lead to a basic school leaving certificate. Thus, students holding either of those comparable degrees can be seen as close substitutes on the labor market and should be equally affected by the emigration of workers with comparable characteristics. Tables 1 and 2 show the distribution of the education levels in the Lithuanian HBS as well as in the Irish census.

I therefore define the education groups as follows: Lower secondary school and less, upper secondary school and third-level degree.

Lower Secondary School AND Less People with 10 years of schooling or less. As the Lithuanian HBS contains very few observations with primary school education or less, I merge these with the category lower secondary school. Therefore, in terms of the Lithuanian classification, this category includes highschool dropouts, workers who only finished primary school, those with a basic school leaving certificate (usually obtained at the age of 16) and those who pursued stage I of vocational training, which also leads to a basic school leaving certificate. In the Irish census, this group consists of primary school and less and lower secondary school.

20 http://www.euroguidance.lt provides an overview of the Lithuanian education system. 
UPPER SECONDARY SCHOOL This category includes all workers having a degree higher than a basic school leaving certificate (i.e. at least 11 years of schooling), but do not hold a degree that would allow them to enter a masters' programme at a university in Lithuania or abroad. The dominant degree in this category is the Lithuanian A-level, usually obtained at the age of 18 . The other degrees of this category are stages II, III and IV of vocational training and certificates from non-university third-level institutions.

In the Irish census, this category contains all workers with an upper secondary school degree or a third-level education that does not lead to a university degree.

THIRD-LEVEL DEGREE All workers with at least 15 years of schooling and a degree that enables them to apply for a university masters' degree in Lithuania or abroad. Workers with a masters' or a PhD degree are also included in this category. 


\section{C.3 TABLES FOR ONLINE APPENDIX}


TABle 5 - RoBUstness CHECKS

Dependent variable: log real wage

\begin{tabular}{ccccc}
\hline \hline$(1)$ & $(2)$ & $(3)$ & $(4)$ \\
$2 y r$ cells & $10 y r$ cells & $2002 \& 2006$ & Irish data \\
\hline
\end{tabular}

\section{A) without interactions}

i) all

$\begin{array}{ccccc}\text { Emigration rate } & 0.535^{* * *} & 0.873^{*} & 1.020^{* *} & 2.089^{* *} \\ {[0.194]} & {[0.454]} & {[0.419]} & {[0.996]}\end{array}$

ii) men/women

$\begin{array}{lcccc}\text { Emigration rate } & 0.242 & 0.645 & 0.764 & 1.236 \\ & {[0.230]} & {[0.444]} & {[0.476]} & {[0.995]} \\ \text { Emig*male } & 0.634^{* *} & 1.055^{* * *} & 0.842^{*} & 2.761^{* * *} \\ & {[0.274]} & {[0.348]} & {[0.434]} & {[0.745]}\end{array}$

B) with interactions

i) all

$\begin{array}{lllll}\text { Emigration rate } & 0.417^{*} & 0.334 & 0.576 & 1.332 \\ & {[0.218]} & {[0.694]} & {[0.648]} & {[1.341]}\end{array}$

ii) $m e n / w o m e n$

\begin{tabular}{lcccc} 
Emigration rate & 0.217 & $1.442^{* *}$ & 0.690 & $1.663^{*}$ \\
& {$[0.226]$} & {$[0.808]$} & {$[0.704]$} & {$[0.952]$} \\
Emig*male & $0.532^{*}$ & $1.625^{* *}$ & 0.637 & $2.773^{* * *}$ \\
& {$[0.272]$} & {$[0.638]$} & {$[0.601]$} & {$[0.826]$} \\
\hline
\end{tabular}

Robust standard errors in brackets

*** $\mathrm{p}<0.01, * * \mathrm{p}<0.05, * \mathrm{p}<0.1$

Note: This table displays the coefficients for a series of robustness checks: 1) 2-year experience cells, 2) 10-year experience cells, 3) only data from 2002 and 2006, 4) only Irish data. Emig*male is an interaction term of the emigration rate and a male dummy. Year dummies, education dummies, experience dummies and personal characteristics are controlled for. Panel A) are estimates of the baseline model in Equation (5). Panel B) enhances the baseline model by the interaction terms year * educ, year $*$ exper, and educ * exper. Robust standard errors in brackets. Standard errors are clustered at the educationexperience-year level. Significance levels: ${ }^{* * *} \mathrm{p}<0.01,{ }^{* *} \mathrm{p}<0.05,{ }^{*} \mathrm{p}<0.1$. 


\section{C.4 Figures FOR ONLINE APPENDIX}
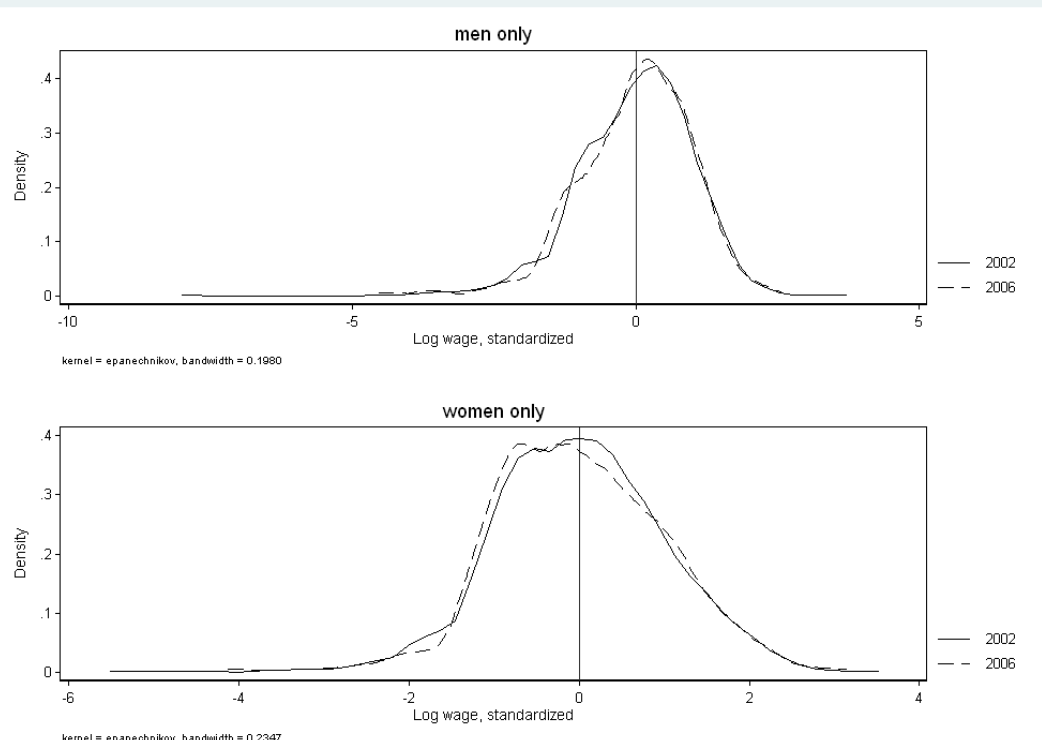

Figure 4 - Standardized Wage Distribution For men And WOMEn in Lithuania, 2002 AND 2006

Note: The graph shows a Kernel density plot of the log real wages in 2002 and 2006 for men and women.

To make the distribution comparable across years, wages are standardized to their z-scores, i.e. the wage of an individual minus the mean wage, divided by the standard deviation of wages, $z_{i}=\left(w_{i}-\bar{w}\right) / \sigma_{w}$. The mean of the distribution is zero. Source: Lithuanian Household Budget Survey 